\title{
日本地下水学会の研究・事業活動と産官学連携
}

\author{
中島 誠* $・$ 端淳一**
}

\section{Research, business activities and industry-government-academia collaboration of the Japanese Association of Groundwater Hydrology}

\author{
Makoto NAKASHIMA* and Junichi KAWABATA**
}

\begin{abstract}
The Japanese Association of Groundwater Hydrology (JAGH) celebrated its 60th anniversary in 2019. For the last 10 years, research and business activities have been conducted while exploring the social role and activities to be performed as a public interest incorporated association. In this article, after looking back on research and business activities over the past 10 years, it was shown how the research and business activities of JAGH should proceed for the next 10 years from a perspective industry-government-academia collaboration.
\end{abstract}

Key Words: reserch activities, business activities, public interest incorporated association, social contribution, industry-government-academia collaboration

要 旨

日本地下水学会は, 2019年をもって設立60周年を迎えた。この10年間は, 公益社団法人として社会 的に果たすべき役割や行うべき活動を模索しながら, 研究・事業活動を行ってきた。本稿では, 日本 地下水学会がこれからの10年間の研究・事業活動をどのように進めていくべきかについて, 最近10年 間の研究・事業活動を振り返った上で, 産官学連携という観点から考えてみた。

キーワード : 研究活動, 事業活動, 公益社団法人, 社会貢献, 産官学連携

\section{1.はじめに}

日本地下水学会（以下「本学会」という。）は 1959年（昭和34年）に設立され，任意団体として 活動してきた後，2009年（平成21年）の一般社団 法人の認定を経て，2010年（平成22年）に公益社 団法人に認定された。そして，2019年（平成31
年・令和元年）には設立60周年を迎えることと なった。設立時の日本地下水学会は水文地質分 野，すなわち理学をバックグラウンドとした学識 者が設立した学会であったが，そこで扱われる問 題は設立当初から，水文地質的な立場からの地域 地下水の研究のみならず，地下水の工業利用，公

\footnotetext{
* 国際航業株式会社（干102-0085 東京都千代田区六番町 2 番地）

** 鹿島建設株式会社（干107-8348 東京都港区赤坂6-5-11 鹿島赤坂別館）
} 
害問題（奥津, $1959 ； 1966)$ といった実学的, 工学的課題への取組が柱の一つであった。その 後, 1980年代後半には, 建設工事における地下水 処理, 1990年代には土壤・地下水污染, そして 2010年以降は温暖化や水循環, SDGs (Sustainable Development Goals: 持続可能な開発目標）といっ た地球規模の問題への対応とまさに学際, 業際に 発生する課題へ対応しながら, 学会は発展してき た。また，最近では2010年度の公益社団法人化以 降, 研究成果の “社会実装”が重要な課題として 注目を浴びるようになってきている。こうした変 遷を見ると, 日本地下水学会はその誕生以来, 常 に産官学の協力の中で発展してきた学会であり, 現況をみれば明らかに, その重要性は増していく だろうと考えられる。本学会では, 学会規約にも 明記されているとおり「地下水資源の保全と有効 利用」, その他地下水に関する諸問題の解決に貢 献し,「社会の発展に寄与」することを目的とし て, 地下水に関する研究, 技術開発および普及に 関する事業を行うことを大きな目的としている。 また，本学会の特徵として，前述したように理 学, 工学, 農学等の幅広い分野の研究者や技術者 を擁し, 会員の所属が大学, 研究機関, 企業およ び行政機関と多彩であることが挙げられ，このよ うな幅広い分野に跨る機関の会員が強く連携して 研究活動や事業活動を行っていることが挙げられ る。

さて本学会は, この10年はどうであったかといえ ば, 公益社団法人化後は, 本学会が公益社団法人 として社会的に果たすべき役割は何か，そのため にどのような活動を行っていく必要があるのかを 模索しながら研究・事業活動が行われた10年間で あったということができる。本稿では, 設立60周 年を迎えた本学会がこれからの10年間の研究・事 業活動をどのように進めていくべきであるかにつ いて, 最近10年間の研究・事業活動を振り返った 上で，産官学連携という観点から考えてみる。

\section{2. 最近10年間の研究・事業活動を振り返って}

\section{1 最近10年間の研究・事業活動に大きな影 響を与えた出来事とそれに対する対応}

最近10年間（2009～2018年度）に本学会の研究.
事業活動に大きく影響を与えた出来事として, 本 学会の公益法人化, 東北太平洋沖地震による東日 本大震災，水循環基本法の施行および水循環基本 計画の策定, 熊本地震の四つが挙げられる。以下 にこれらに対する地下水学会の対応をまとめる。

\section{（1）日本地下水学会の公益法人化}

2010年 8 月 5 日に本学会が公益社団法人に認定 されたことにより, 公益社団法人として学会活動 はどうあるべきか，学会としてどのようなかたち で社会貢献できるのか，また，していくべきかな どが理事会や各常設委員会において議論される機 会が増え, 公益事業としての研究活動や事業活動 の活発化（活動の幅の拡大や量の増加）につな がった。このような議論は, 2011年 3 月に東日本 大震災が発生したことを受け, さらに促進されて きた。

2015年には, 谷口真人会長からの依頼により, 本学会の将来構想を検討するための将来構想ワー キンググループ (以下「WG」)（座長：德永朋祥） が理事会, 代議員会, 常設委員会からの代表者を 集めて設置され, 2016年に, 検討結果として, 本 学会のミッション, 本学会のミッションと会長ビ ジョン（谷口，2015）に基づくアクションプラン (案)，アクションプランを実施するに当たっての 留意点が答申された。これによれば, 本学会の ミッションは「地球の水循環を構成する地下水に 関して, 学際的領域において俯瞰的視野に立ち, 地下水を正しく理解し, 現在および将来にわたっ て地下水資源を保全・有効利用するための活動を 行い, 持続可能な社会の発展に貢献する」ことで あり，本学会が行うべき活動としては，(1)地下水 に関わる諸問題の解決のための研究・技術開発, (2)地下水に関する科学技術の理解促進と普及啓 発，(3)学会員の専門能力の継続的な向上と人材教 育・国際教育，(4)環境，社会，文化，経済，政治 等への影響を認識した科学技術成果に基づく意思 決定の支援の四つに集約されることが示された。

また, 社会活動, 若手支援, 他機関との連携・協 働, 国際化の四つのカテゴリーに対して具体的に 進めていくことが必要なまたは望ましい内容がア クションプランとして整理され，それに対する関 連常設委員会のロードマップ（以下「アクション プラン対応ロードマップ」という。）も示された 
(德永, 2017)。

現在は，このアクションプランおよびアクショ ンプラン対応ロードマップの内容の実現に向け て, 各常設委員会の研究活動および事業活動が検 討され，それぞれ実施されている状況にある。

\section{（2）東日本大震災とそれを受けての活動}

2011年 3 月11日の東北太平洋沖地震による東日 本大震災（地震動・津波による被害および福島第 一原子力発電所事故）の発生を受けて，本学会は 水文・水資源学会との合同調查団 (水文・水資源 学会東日本大震災対応地下水調查研究グループ,

代表：開發一郎）を組織し, 2011年 6 月と 8 月に 釜石市, 陸前高田市, 南三陸町において水源井戸 の地下水への津波による影響調査を行った。この 調査結果は2011～2012年に両学会で速やかに報告 されるとともに（開發ほか，2010；2011），2012 年 5 月に開催された本学会主催のシンポジウム 「震災時の非常用水源としての地下水利用の在り 方」で報告され (谷口. 中島, 2013), 地下水学 会誌の特集「震災と地下水」にも資料として揭載 された（中川ほか，2013）。

東日本大震災に関する研究活動としては, 上記 の合同調査団による調査のほか, 本学会内に調査 研究チームを構築して研究を進める研究計画を作 成し, 東日本大震災復興助成に応募した。結果は 地元との連携や体制強化が不可欠である等の理由 で不採択に終わったが, 産官学連携による研究体 制を本学会内に構築し, 外部資金を得て社会貢献 につながる研究活動を行う計画を具体化したとい う点で, 本学会における産官学連携研究構想を考 えていく上で一つの方向性を示したと考えられ る。

東日本大震災では, 地震動や津波により, 水道 施設等の破損による断水の継続, 地下水の塩水化 や污染, 原子力発電所事故による放射性物質の環 境中への放出等の様々な被害が発生し, 生活用水 の応急的な確保, 塩水化した地下水や污染された 地下水の水質の回復, 放射性物質による污染水の 流出防止や表層水および地下水を通じた放射性物 質の拡散の防止等, 地下水に関して数多くの課題 が顕在化した。本学会では, これらに関する社会 的な課題や調查研究に関する情報を共有化し, 今 後の社会的な取り組みや調查研究に生かしてもら
うことを意図したセミナーや，さらに社会的な課 題の解決に向けた今後の取り組みのあり方に関す る討論まで行うシンポジウムを開催し, 会員およ び社会への情報提供を行った。

\section{（3）水循環基本法の施行および水循環基本計画 の策定を受けての活動}

水循環基本法が2014年 4 月 2 日に公布され, 同 年 7 月 1 日に施行された。本学会では, 水循環基 本法の制定・公布を受けて，2014年 5 月23日に水 関連 5 団体の後援を得てセミナー「なぜ，水循環 基本法なのか」をいち早く開催し，様々な観点か ら水循環基本法制定後に期待, 予想される変化等 について議論した。同年 7 月 1 日には，上記セミ ナーでの議論および地下水分野の有識者からの意 見を踏まえた「水循環基本法に基づく水循環基本 計画 ·水関連法案制定への提言」を内閣府水循環 政策本部, 水制度改革議員連盟（以下「議連」と いう。）および自由民主党水戦略特命委員会に対 して行った（嶋田・谷口, 2014）。その後, 議連 および議連の中に設置された「水循環基本法フォ ローアップ委員会 (以下「フォローアップ委員会」 という。）から本学会宛てに「地下水保全法案の 策定についてのご協力のお願い」が届いたことを 受け，この提言に対する具体的な施策・事業等に 対して, 学会として積極的に取り組むための議論 をする場として本学会内に「水循環基本法ワーキ ンググループ $(\mathrm{WG}) 」$ (委員長 : 谷口真人)を設 置した。

同年12月 8 日には, フォローアップ委員会に嶋 田純会長と谷口真人 WG リーダーが出席し,「地 下水学会からの提言（2014年 7 月 1 日）に基づく 地下水保全法（仮）への意見」を表明した。そし て, 水循環基本法WGにおいて日本地下水学会 「地下水の保全，涵養及び利用に関する法律(案)」 (略称「地下水保全法 (案)」) を作成し，2015年 1 月 7 日の水循環政策分科会地下水保全法案起草 委員会 (以下「起草委員会」という。) において, 日本地下水学会案として提示した(田中, 2016)。

起草委員会では，本学会案を含む三つの案に基 づいて審議され，2015年 2 月17日に「地下水の 保全, 涵養及び利用に関する法律（地下水保全 法) 案」がフォローアップ委員長から議連代表に 上申されるに至ったが, 諸般の事情から予定され 
ていた第189回国会への上程は見送られた（田中 (2016)。

水循環基本計画に対しては，2016年 4 月に本 学会内に「水循環基本計画ワーキンググループ (WG)」（委員長：川端淳一）を設置した。水循 環基本計画 WG では, 水循環基本計画が実際に 実効性のあるかたちで社会に反映され，その中で 地下水が持続可能なかたちで有効利用および保全 されているためにはまだ多くの取り組むべき課題 が残されていることから, それらの課題を具体化 し，社会に認識してもらうための活動を行うため の活動計画を検討し，「水循環基本計画に関わる 学会活動のロードマップ (案)」を立案した。現 在は, 実施項目として挙げられた内容について, 承認された「水循環基本計画に関わる学会活動の ロードマップ」(以下「水循環基本計画対応ロー ドマップ」という。）に則って各常設委員会が活 動するよう努めている状況にある。

これら水循環基本法および水循環基本計画に対 する一連の対応では, 本学会の会員の多くを占め る自然科学系の研究者や技術者だけでなく, 法学 分野の研究者も委員としてWGに参加した。

\section{（4）熊本地震とそれを受けての活動}

2016年 4 月14日および16日に発生した熊本地震 を受けて, 本学会では, 学会内に熊本地震対応調 查・研究グループを組織し, 熊本大学の「熊本地 震による地下水環境への影響評価プロジェクト」 と協力研究体制をとって研究活動を行ってきた。 この熊本大学のプロジェクトは支援企業であるサ ントリーおよび地下水保全対策実施機関である 「くもと地下水財団」と連携して進められてい
るものであり, 産官学連携研究の一つのかたちで あるといえる。

熊本地震対応調査・研究グループでは, 熊本県 を中心に, 連続して一連の地震が発生した地域に 扮ける地下水・水文環境に関する情報を収集・共 有化し, 今後の防災・減災に役立つ知見・情報を 一般化して地域住民や国民に還元するとともに， 本格的な研究につなげることを目的として, 活動 が行われている。

本研究グループは, 中間的な研究成果を速報 として2017年秋季講演会で報告するとともに， 2018年 5 月の日本地球惑星科学連合2018年大会 の特別セッション「熊本地震にともなう地表水 と地下水の変化」, 同年 9 月の IAH 2018（韓国 大田）の日本地下水学会特別セッション「Effect of 2016 Kumamoto Earthquake (M7.3) to the local groundwater system」で報告しており，学術的な 貢献を果たしてきた。また，2019年 4 月には, サ ントリー熊本みらいプロジェクト主催で同プロ ジェクト公開シンポジウム「巨大地震が熊本の地 下水環境に与えた影響の科学的解明 一日本地下 水学会熊本調查研究グループ活動による成果報 告一」が熊本市にて開催され, 熊本地震対応調査. 研究グループの研究成果が地域住民を中心に社会 に広く還元された。

この熊本地震対応調査・研究グループの設置およ び活動がスムーズに進められた背景として, 東日 本大震災の際にこのような災害発生時に本学会は どのような対応をとるべきかについて議論が重ね れられた経験が有効に機能したことが挙げられる。

表 1 最近 10 年間に活動した研究グループ（2009〜 2018 年度）

\begin{tabular}{|c|c|}
\hline 活動年度 & 研究グループ名 \\
\hline $2004 \sim 2009$ & 「深層地下水環境研究会」研究グループ \\
\hline $2006 \sim 2009$ & 地下水流動解析理論のとりまとめに関する研究グループ \\
\hline $2009 \sim 2010$ & 地下水の人工涵養方法に関する研究グループ \\
\hline $2009 \sim 2015$ & 地球温暖化と地下水の水資源評価に向けた課題抽出研究グループ \\
\hline $2009 \sim 2012$ & 地下熱利用技術の高度化と普及促進に関する研究グループ \\
\hline $2013 \sim 2015$ & 地下水学の名著を読む研究グループ \\
\hline $2015 \sim 2016$ & 地下水流動解析における V\&V 対応の課題抽出研究グループ \\
\hline $2016 \sim$ & 熊本地震対応調査・研究グループ \\
\hline $2017 \sim$ & 地下水ガバナンス等に関する調査・研究グループ \\
\hline $2017 \sim$ & 水循環における地下水の科学に関する調査・研究グループ \\
\hline $2017 \sim$ & 地下水流動解析コード検証事例作成のための調査・研究グループ \\
\hline $2018 \sim$ & 降雨浸透過程モデリングに関する研究委員会 \\
\hline
\end{tabular}




\section{2 最近10年間の研究活動}

最近10年間（2009 2018年度）に本学会が行っ た研究活動には, 東日本大震災に対応した水文. 水資源学会と本学会の合同調査団 (水文水資源学 会東日本大震災対応地下水調查研究グループ, 代 表：開發一郎）による活動と,この間に活動した 表 1 に示す 12 の研究グループ(研究委員会を含む) の活動，および調查・研究委員会による「地域地 下水情報データベース」の作成・学会ホームペー ジ上での公開がある。

水文 ·水資源学会東日本震災対応地下水研究グ ループの研究活動については, 2.1(2) で前述し たと㧍りである。

\section{（1）研究グループ活動}

表 1 に示す通り，12の研究グループのうち， 7 グループがこれまでに活動を終了している。これ ら12グループのうち半数以上は調査・解析等, 地 下水の利用や涵養に関わる技術やその普及に関わ る研究グループとなっており, 他には気候変動 （地球温暖化を含む）による地下水資源への影響 とその評価方法, 水循環の構成要素としての地下 水の自然科学的知見や社会科学的知見等を研究対
象とするグループも活動してきた。

これらの研究グループでは, 自然科学系の幅広 い分野の研究者や技術者が産官学（この場合の官 は主として国立または公立の研究機関）それぞれ の機関から委員として参画し, 連携しながら研究 活動が進められている。また, 社会科学的な要素 も関係してくる「地球温暖化と地下水の水資源評 価に向けた課題抽出研究グループ」や「地下水ガ バナンス等に関する調査・研究グループ」では, 社会科学的な観点からの検討も必要になることか ら, 自然科学系の研究者や技術者だけでなく, 社 会科学系の研究者の参画も得て, 研究が行わ机て いる。特に「地下水ガバナンス等に関する調査・ 研究グループ」の場合は, テーマ自体が社会科学 的な内容であることもあり, 社会科学系の研究者 が中心となって研究が進められている。さらに外 部の研究プロジェクトと連携して研究を進める 「熊本地震対応調查・研究グループ」のようなか たちは, 社会連携あるいは産官学連携という点で 今後の参考になるものであると考えられる。

研究グループ活動の成果は, シンポジウム, セ ミナー，あるいは春季・秋季講演会に扔ける特別

表 2 最近 10 年間に開催されたシンポジウム・セミナー等（2009～2018 年度）

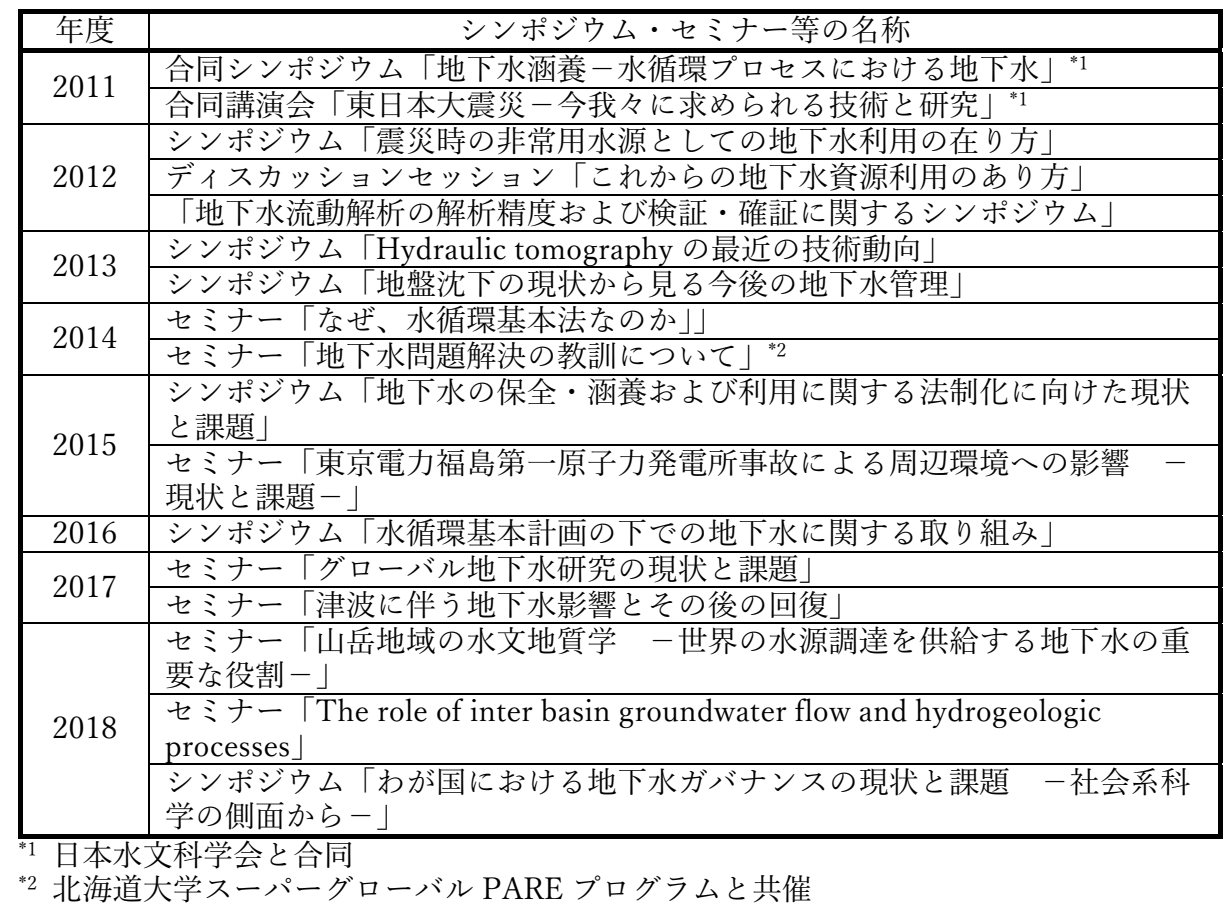


表 3 最近 10 年間に秋季講演会と同時開催されたシンポジウム（2009～2018 年度）

\begin{tabular}{|c|c|c|}
\hline 年度 & シンポジウムのタイトル & 開催地 \\
\hline 2009 & 北海道の地下水資源をどう生かしどう衛るか & 札幌市 \\
\hline 2011 & 瀬戸内の地下水 & 広島市 \\
\hline 2012 & 地下水のいま そして未来 & 鹿児島市 \\
\hline 2013 & 秋田の多様な水 －環境・資源－ & 秋田市 \\
\hline 2014 & $\begin{array}{l}\text { 地下水流動に伴う帯水層中での硝酸性窒素の振る舞い } \\
\text { ド調査・室内試験・モ゙ルール }\end{array}$ & 熊本市 \\
\hline 2015 & 人といきものを育む地下水 & 大野市 \\
\hline 2016 & 地下水管理における意思決定に係わる水文地質観測 & 長崎市 \\
\hline 2017 & 地下水と地熱・地中熱エネルギーの利用 & 弘前市 \\
\hline
\end{tabular}

表 4 最近 10 年間に開催された講習会（2009～2018 年度）

\begin{tabular}{|c|c|}
\hline 年度 & 講習会名 \\
\hline 2009 & 「地下水のトレーサー試験」講習会 \\
\hline 2010 & 地下水シミュレーション講習会 \\
\hline 2011 & 地下水シミュレーション（実習）講習会 \\
\hline 2012 & 地下熱利用（熱応答試験およびその解析）講習会 \\
\hline 2013 & $\begin{array}{l}\text { 地下水シミュレーション（実習）講習会 } \\
\text { 現場調查(揚水試験) 講習会"11 }\end{array}$ \\
\hline 2014 & $\begin{array}{l}\text { 地下水シミュレーション（初級）講習会 } \\
\text { 現場調査 (水文調査) 講習会 }\end{array}$ \\
\hline 2015 & $\begin{array}{l}\text { 地下水シミュレーション（入門）講習会 } \\
\text { 現場調査 (水文調査) 講習会 }\end{array}$ \\
\hline 2016 & $\begin{array}{l}\text { 地下水シミュレーション（移流分散解析）講習会 } \\
\text { 現場調査講習会「はじめての揚水試験講習会」 }\end{array}$ \\
\hline 2017 & $\begin{array}{l}\text { 地下水シミュレーション（入門）講習会 } \\
\text { 現場調査講習会「はじめての揚水試験習会」 }\end{array}$ \\
\hline 2018 & $\begin{array}{l}\text { 現場調査（水文調査）講習会 } \\
\text { 地下水シミュレーション移流分散解析）講習会 }\end{array}$ \\
\hline
\end{tabular}

表 5 最近 10 年間に地下水学会誌に掲載された特集・小特集（2009〜2018 年度）

\begin{tabular}{|c|c|}
\hline 特集・小特集のタイトル & 掲載巻・号 $($ 年) \\
\hline 地下水の開発と保全・管理－日本の経験とこれからの挑戦 & 52 巻 1 号 $(2010)$ \\
\hline 地下水流動系と熱／物質輸送 & 52 巻 4 号 $(2010)$ \\
\hline 東日本大震災と地下水 & 54 巻 1 号 $(2012)$ \\
\hline 震災と地下水 & 55 巻 1 号 $(2013)$ \\
\hline これからの地下水資源の利用のあり方 & 55 巻 2 号 $(2013)$ \\
\hline 地下水流動解析の高度化手法と検証・確認 & $\begin{array}{l}56 \text { 巻 } 3 \text { 号 }(2014) \\
57 \text { 巻 } 3 \text { 号 }(2015)\end{array}$ \\
\hline 秋田の多様な地下水－環境・資源－ & 56 巻 4 号 (2014) \\
\hline 地盤沈下の現状から見る今後の地下水管理 & 57 巻 1 号 $(2015)$ \\
\hline 水循環基本法 & 57 巻 1 号 $(2015)$ \\
\hline 九州・沖縄地域における帯水層での硝酸性窒素の動態 & $\begin{array}{l}57 \text { 巻 } 4 \text { 号 }(2015) \\
58 \text { 巻 } 1 \text { 号 } \\
(2016)\end{array}$ \\
\hline 地下水の保全、涵養及び利用に関する法制度化に向けた現状と課題 & $\begin{array}{l}58 \text { 巻 } 2 \text { 号 }(2016) \\
58 \text { 巻 } 3 \text { 号 }(2016)\end{array}$ \\
\hline 地下水管理における意思決定に係わる水文地質観測 & 59 巻 1 号 $(2017)$ \\
\hline 水循環基本計画の下での地下水に関する取り組み & $\begin{array}{l}59 \text { 巻 } 4 \text { 号 }(2017) \\
60 \text { 巻 } 1 \text { 号 }(2018) \\
60 \text { 巻 } 2 \text { 号 }(2018)\end{array}$ \\
\hline 地下水－地表水交流過程 ; その物質輸送および生態系への影響 & 60 巻 2 号 $(2018)$ \\
\hline 地下水と地熱・地中熱エネルギーの利用 & 60 巻 4 号 $(2018)$ \\
\hline
\end{tabular}


セッション等での講演・発表や, 書籍の出版, 地 下水学会誌での特集・小特集としての報告や誌面 講座としての掲載等により会員および社会に還元 されている。

\section{（2）地域地下水情報データベースの作成・公開}

地域地下水情報データベースの作成・公開で は, 水循環基本計画に基づき地方自治体が中心と なり流域単位で地域特性に合った地下水マネジメ ントを進めていくのに貢献するため, 地域の地下 水に関わる情報に言及した論文・資料等を地下水 盆・地下水区ごとに収集・分類し, ホームペー ジ上で閲覧可能なものについて原文PDF または 原文公開ページヘのリンクを付して紹介すること を行っている。データベースの内容はこれからも 充実されていく予定であり，これまでに地下水学 会誌と水文・水資源学会誌の揭載記事拉よび「日 本の地下水」（農業用地下水研究グループ, 1986) の地下水盆・地下水区の説明ページが掲載されて いる。

\section{3 最近10年間の事業活動}

最近10年間（2009 2018年度）における本学会 が行った事業活動として, 表 2 に示すシンポジウ ム・セミナー等の開催, 表 3 に示す秋季講演会と のシンポジウムの同時開催, 表 4 に示す講習会の 開催および表 5 に示す地下水学会誌での特集・小 特集の掲載, および書籍の出版がある。

シンポジウム・セミナー等については, 公益社 団法人化する以前に比べて大幅に開催件数が増え ており, 内容的にも東日本大震災（福島第一原子 力発電所事故を含む。）や水循環基本法·水循環 基本計画 - 地下水保全法案等, 社会的な問題や課 題に対する知見や情報を都度会員および社会に夕 イムリーに提供してきた。

シンポジウムには, 地方で開催される秋季講演 会と同時に開催されるものもあり, 開催地周辺の 自治体や企業等の協力を得て, 開催地周辺の地域 的な地下水事情を反映したテーマで開催されてい る。この秋季講演会と同時開催されるシンポジウ ムは, 秋季講演会に参加した会員らが地域の実情 を学ぶ機会を提供していると同時に，一般市民の 方々に自分が住む地域の地下水について学ぶ機会 を提供している。
講習会について, 本学会は, 1990年より継続し て地下水シミュレーション講習会を行ってきてお り，地下水シミュレーション技術者の育成に貢献 してきている。また，2013年からは，新たな試み として, 現場調査講習会を開始した。これは, 現 場調査のノウハウをもつベテラン技術者が定年を 迎え, 次世代の技術者への技術の伝承が課題と なってきたことから企画されたものであり，これ までに揚水試験と水文調査をテーマに, 現地実習 もあるかたちで行われている。

地下水学会誌では, 最近10年間で15の特集・小 特集が行われている。内容としては, 最先端の学 術研究や技術に関わるものと社会的な問題や課題 に関するものに大きく分けられ，後者においては 本学会主催で開催したシンポジウム・セミナー等 (秋季講演会と同時開催したシンポジウムを含む) を受けて企画されたものが多くを占めている。

書籍については, 50周年記念事業として企画 された「見えない巨大水脈 地下水の科学」（日 本地下水学会 ·井田徹治, 2009), 「新・名水を 科学する一水質データから見た環境」（日本 地下水学会編, 2009), 「地下水のトレーサー試 験 一地下水の動きを知る」（日本地下水学会原 位置トレーサー試験に関するワーキンググループ 編，2009）,「地下水シミュレーション一これだ けは知っておきたい基礎理論」（日本地下水学会 地下水流動基礎理論のとりまとめに関する研究グ ループ編, 2009), 「地下水用語集」(日本地下水 学会編，2011）の 5 冊を2009年および2011年に出 版した。

また，こうした活動と並行して，本学会では， 一般市民向けの事業活動として, 湧水巡り, 地下 水に関する質問コーナー, 地下水ブックガイドの 公表等により，地下水の保全と有効利用に向けた 啓発活動も行ってきた。

\section{3. これからの10年間の研究・事業活動について}

これまでの10年間をべースにして，これからの 10年間（2009～2018年度）, 当学会の特徵である学 際性, 業際性を生かして, 産官学が連携しながら どのように活動を行っていくべきか，会員意見の 聴取, 理事会, 代議員会での議論を踏まえ, 本学 
表 6 水循環基本計画に関わる学会活動のロードマップの内容

\begin{tabular}{|c|c|c|c|c|c|}
\hline 分類 & 実施項目 & 2017 年度 & 2018 年度 & 2019 年度 & 2020 年度〜 \\
\hline $\begin{array}{l}\text { 統括組織 } \\
\text { による管 } \\
\text { 理 }\end{array}$ & $\begin{array}{l}\text { 行動計画全般の管理 } \\
\text { 成果まとめ、計画の } \\
\text { 見直し修正 }\end{array}$ & ·見直し & •まとめ、見直し & ·見直し & $\begin{array}{l}\text { ※水循環基本計 } \\
\text { 画改訂の可能 } \\
\text { 性 } \\
\text { •まとめ、見直し }\end{array}$ \\
\hline \multirow[t]{4}{*}{$\begin{array}{l}\text { 研究成 果 } \\
\text { 等の公開 }\end{array}$} & $\begin{array}{l}\text { 水循環の中の地下水に } \\
\text { 関する自然科学的な知 } \\
\text { 見の整理および公表 } \\
\text { 【調査・研究、企画】 }\end{array}$ & $\begin{array}{l}\cdot \text { ·調査・研究委員 } \\
\text { 会で内容検討 } \\
\text { ·参加者募集、委 } \\
\text { 員会立ち上げ }\end{array}$ & $\begin{array}{l}\text { ·自然系 G によ } \\
\text { る委員会活動 }\end{array}$ & $\begin{array}{l}\cdot \text { 自然系 G によ } \\
\text { る委員会活動 } \\
\text { ·知見のとりま } \\
\text { とめ、公表 (出 } \\
\text { 版等) }\end{array}$ & $\begin{array}{l}\text { ·自然系 Gによ } \\
\text { る委員会活動 }\end{array}$ \\
\hline & $\begin{array}{l}\text { 水循環の中の地下水に } \\
\text { 関する社会科学的な観 } \\
\text { 点の研究レポートの公 } \\
\text { 表【調査・研究】 }\end{array}$ & $\begin{array}{l}\cdot \text { ·調査・研究委員 } \\
\text { 会で構想検討 } \\
\text { 委員立ち上 } \\
\text { げ、参加者募集 }\end{array}$ & $\begin{array}{l}\text { ・社会系 G によ } \\
\text { る活動 }\end{array}$ & $\begin{array}{l}\text { ・社会系 Gによ } \\
\text { る活動 } \\
\text { ・レポート公表 }\end{array}$ & $\begin{array}{l}\text { ・社会系 G によ } \\
\text { る活動 }\end{array}$ \\
\hline & $\begin{array}{l}\text { 地域の地下水に関する } \\
\text { 研究論文・資料等を学 } \\
\text { 会 HP 上で紹介【調査· } \\
\text { 研究、広報・IT】 }\end{array}$ & $\begin{array}{l}\cdot \mathrm{HP} \text { でデータベ } \\
\text { ース (DB) 公 } \\
\text { 開開始 } \\
\cdot \text { 充実化検討 } \\
\cdot \text { 地域 } \mathrm{G} \text { の参加 } \\
\text { 者募集 }\end{array}$ & $\begin{array}{l}\cdot \text { ·地域 G による } \\
\text { 活 動 } \\
\cdot \text { DB 更新 }\end{array}$ & $\begin{array}{l}\cdot \text { 地域 G による } \\
\text { 活動 } \\
\cdot \text { DB 更新 }\end{array}$ & $\begin{array}{l}\cdot \text { 地域 G による } \\
\text { 活動 } \\
\cdot \text { DB 更新 }\end{array}$ \\
\hline & $\begin{array}{l}\text { 地下水に関する各種デ } \\
\text { ータベース等へリンク } \\
\text { する公口サイトの公開 } \\
\text { 【広報・IT】 }\end{array}$ & $\begin{array}{l}\text { ·掲載内容の検 } \\
\text { 討 }\end{array}$ & $\begin{array}{l}\cdot \text { ·初期版の作成 } \\
\text { ·初期版の公開 }\end{array}$ & $\begin{array}{l}\text { ·更新管理の継 } \\
\text { 続 }\end{array}$ & $\begin{array}{l}\text { ·更新管理の継 } \\
\text { 続 }\end{array}$ \\
\hline \multirow[t]{3}{*}{$\begin{array}{l}\text { 研究 活 動 } \\
\text { 等の支援 }\end{array}$} & $\begin{array}{l}\text { 地域の研究者、地下水 } \\
\text { 関係の取組等の支援 } \\
\text { 【渉外、各委員会】 }\end{array}$ & $\begin{array}{l}\cdot \text { ・ニーズ、取組情 } \\
\text { 報等の収集 } \\
\text { ・体制検討 }\end{array}$ & - 試行的に実施 & ·全国に展開 & ·全国に展開 \\
\hline & $\begin{array}{l}\text { 秋季講演会時の小中高 } \\
\text { 校生セッシン企 } \\
\text { 【行事】 } \\
\text { 高校生(スーパーサイ } \\
\text { エンスハイスクール } \\
\text { 等)のサポート【渉外】 }\end{array}$ & $\begin{array}{l}\text { ・ニーズ、手法等 } \\
\text { の検討 }\end{array}$ & $\begin{array}{l}\cdot \text { 講演会等に合 } \\
\text { わせて開催 }\end{array}$ & $\begin{array}{l}\text { ・講演会等に合 } \\
\text { わせて開催 }\end{array}$ & $\begin{array}{l}\text { ·講演会等に合 } \\
\text { わせ型催 }\end{array}$ \\
\hline & $\begin{array}{l}\text { シンポジウム・ワーク } \\
\text { ショップの開催【企画、 } \\
\text { 調査・研究】 }\end{array}$ & $\begin{array}{c}\cdot \text { ·水循環系で年 } 1 \\
\text { 回以上開催 }\end{array}$ & $\begin{array}{c}\cdot \text { ·水循環系で年 } 1 \\
\text { 回以上開催 }\end{array}$ & $\begin{array}{c}\cdot \text { ·水循環系で年 } 1 \\
\text { 回以上開催 }\end{array}$ & $\begin{array}{c}\text { ·水循環系で年 } 1 \\
\text { 回以上開催 }\end{array}$ \\
\hline $\begin{array}{l}\text { メディア } \\
\text { の活用 }\end{array}$ & $\begin{array}{l}\text { メディアへの情報提供 } \\
\text { 【広報・IT】 }\end{array}$ & $\begin{array}{l}\text { ·水循環に関す } \\
\text { る活動を HP } \\
\text { 等で PR } \\
\text { ・水循環に関す } \\
\text { る素材等の作 } \\
\text { 成 }\end{array}$ & $\begin{array}{l}\text { ・水循環に関す } \\
\text { る活動を HP } \\
\text { 等で PR } \\
\text { マ マスコミ等へ } \\
\text { の素材等の提 } \\
\text { 供 }\end{array}$ & $\begin{array}{l}\text { ・水循環に関す } \\
\text { る活動を HP } \\
\text { 等で PR } \\
\text { ・マスコミ等へ } \\
\text { の素材、リリ } \\
\text { ース等の提供 }\end{array}$ & $\begin{array}{l}\text { ・水循環に関す } \\
\text { る活動を HP } \\
\text { 等で PR } \\
\text { ・ マスコ等へ } \\
\text { の素材、リリ } \\
\text { ース等の提供 }\end{array}$ \\
\hline
\end{tabular}

会のアクションプラン対応ロードマップを随時改 定しながら発展させていくことが望ましい。

例えば，水循環基本計画に対する対応について は，先に述べた水循環基本計画対応ロードマッ プ（表 6）を基に精力的に活動が行われており， 地下水ガバナンス等に関する調查・研究グループ の活動成果も近々とりまとめられる予定となって いる。今後はそれを基に, さらに水循環基本計画 対応ロードマップを改定しながら“産官学”で一 体となった対応をすすめていくことが望ましい。 本課題に対してはSDGs，気候変動というグロー バルな視点から自然科学の摂理に基づいた適切な 管理方法を提案すべきであること，複数の自治 体，周辺住民を巻き込んで流域ベースの実効的な マネジメント手法を社会実装する必要があること
という二つの大きな課題がある。これに対して, 産官学で実効的に取り組む方法としては，例えば SDGsへの民間の関心を取り込んだ検討を行うと いうことが挙げられる。今後の民間投資が実際に $\mathrm{SDGs}$ 関連に向かうであろうとの指摘は省庁や金 融系の資料等でも指摘されており（例えば，金融 庁, 2018 ; 経済産業省, 2018 ; 金融調査研究会, 2019），水循環の管理手法についても，SDGs へ の貢献をベースにしつつ, ICT（Information and Communication Technology: 情報通信技術）やAI (Artificial intelligence: 人工知能) といった先端技 術等を取り入れたデー夕管理手法を提案する等の 効果的なアイディアがあれば，民間を巻き込んだ 研究開発がしやすくなる。また, 社会実装につい ては，その主体である“官”を効果的にサポート 
できる施策が必要であり, 社会科学的視点からの 検討が現在，実際に地下水ガバナンス等に関する 調查・研究グループで進められつつある。地下水 学会は, これら全体の活動をオーガナイスできる “産”, “官”, “学”の人材が揃った学会であり, 社会に貢献できる成果を創出するため粘り強く課 題に向き合っていくことが必要である。

最後に全体として産官学の人材連携を生かして 学会を発展させ, かつ社会に貢献していくための 施策として考えうる事項を列記する。

- 水循環基本計画の社会実装への貢献, 地下水ガ バナンス等に関する調査・研究グループの成果 の効果的発信（地下水学会のみならず, 学会発 の成果としての他学会での発表, 議論等)

・産官学連携に基づく外部研究資金の導入

- GNSS (Global Navigation Satellite System: 全球 測位衛生システム), ICT, AI 等グローバルに イノベーションが進む先端技術を生かした研究 開発の推奨（ビッグデータの取得とそれを活用 した研究, 先端的センシング技術を適用するた めの研究等)

・引き続き進む, 国土開発と地下水保全に関する 研究 (リニア新幹線プロジェクト, 都市地下再 開発等と地下水保全の関係)

- 防災, 減災と地下水との関係

・地下水に関わる諸課題の解決を担っていく人材 の教育

\section{4. おわりに}

地下水学会の最近10年間の活動を振り返り, 今 後取り組むべき課題について産官学連携という視 点から述べた。国民共有の財産である地下水資源 を取り扱う学術団体として, 社会に根を張りながら 地下水学を健全に発展させていくことが望まれる。

\section{参考文献}

奥津春夫 (1959): 仙塩臨海工業地帯の地質と工業用水.

日本地下水学会誌, 1 (1), 1-2.

奥津春夫（1966）: 地域開発にあらわれつつある地下水

の公害. 日本地下水学会誌, 8(2), 9-13.

開發一郎·德永朋祥·近藤明彦· 中川 啓. 小野寺真一

林 武司·手計太一・嶋田 純·勝見 武·村田正敏 -
和田直之 (2011) : 日本地下水学会と水文 ·水資源学 会の連携による東日本大震災対応地下水調査研究の 予備的報告. 日本地下水学会2011年秋季講演会講演 要旨, 162-163.

開發一郎·德永朋祥・ 小野寺真一 - 林 武司 - 手計太一 嶋田 純 - 中川 啓 - 和田直之 - 勝見 武 - 村田正 敏 (2012) : 日本地下水学会と水文・水資源学会の連 携による東日本大震災対応地下水調查研究の報告 (そ の 2 ). 水文·水資源学会2012年度研究発表会要旨集.

金融庁 (2018)；金融行政と SDGs. 20p., https://www.

fsa.o.jp/policy/sdgs/FSAStrategyforSDGs.pdf (2019 年11月22日閲覧）

金融調査研究会（2019）：SDGsは金融とどう向き合う のか. 32p.

経済産業省経済産業政策局産業資金課（2018）：事 務局説明資料. 第 1 回 SDGs 経営 / ESG 投資研究 会資料 5 , 42p., https://www.meti.go.jp/shingikai/ economy/sdgs_esg/pdf/001_05_00.pdf（2019年11月 22日閲覧）

沜田 純・谷口真人（2014）：水循環基本法に関する学 会からの提言. 地下水学会誌, 56 (3), 187-188.

田中 正 (2016)：地下水保全法案の作成経過とシンポ ジウム総合討論のまとめ - 地下水保全法のあるべ き姿を目指して一。地下水学会誌, 58 (3)，315-341. 谷口真人 (2015) : 会長メッセージ 持続可能な社会に 向けての地下水ガバナンス. 地下水学会誌, 57(3), 276. 谷口真人・中島 誠 (2013)：シンポジウム「震災時の 非常用水源としての地下水利用の在り方」. 地下水学 会誌, 55 (1), 37-64.

德永朋祥 (2017)：地下水学会のミッションとその実現 に向けて. 地下水学会誌, 59 (2), 83-84.

中川 啓・和田直之 ·開發一郎 - 德永朋祥 - 近藤昭彦 小野寺真一・林 武司·手計太一・嶋田 純·勝見 武. 村田正敏 (2013) : 平成23年東北地方太平洋沖地震の 津波による水源地下水への影響について. 地下水学 会誌, 55 (1), 21-28.

日本地下水学会編（2009）: 新・名水を科学する - 水 質データから見た環境. 技報堂出版, $312 \mathrm{p}$.

日本地下水学会編（2013）：地下水用語集. 理工図書,

143p.

日本地下水学会・井田徹治 (2009): 見えない巨大水

脈 地下水の科学. 講談社, $267 \mathrm{p}$.

日本地下水学会地下水流動解析基礎理論のとりまとめ 
地下水学会誌 第 62 巻第 1 号 $15 ２ 4$ (2020)

に関する研究グループ編（2009）：地下水シミュレー ションーこれだけは知っておきたい基礎理論。技 報堂出版, 232p.

日本地下水学会原位置トレーサー試験に関するワー キンググループ編（2009）：地下水のトレーサー試
験 一地下水の動きを知る. 技報堂出版, 383p.

農業用地下水研究グループ（1986）：日本の地下水. 地 球社, 1043p.

(受付：2019年 9 月 1 日, 受理：2019年12月 1 日) 